\title{
Tenacibaculum crassostreae sp. nov., isolated from the Pacific oyster, Crassostrea gigas
}

Correspondence

Jae Sung Jung

jjung@sunchon.ac.kr

\author{
Young Sun Lee, ${ }^{1}$ Keun Sik Baik, ${ }^{1}$ So Yeon Park, ${ }^{1}$ Eun Mi Kim, ${ }^{1,2}$ \\ Dong-Heon Lee, ${ }^{3}$ Hyung-Yeel Kahng, ${ }^{3}$ Che Ok Jeon ${ }^{4}$ \\ and Jae Sung Jung ${ }^{1}$
}
${ }^{1}$ Department of Biology, Sunchon National University, Suncheon 540-742, Republic of Korea
${ }^{2}$ Department of Dental Hygiene, Gwangju Health College University, Gwangju 506-701, Republic of Korea
${ }^{3}$ Department of Environmental Education, Sunchon National University, Suncheon 540-742, Republic of Korea
${ }^{4}$ Department of Life Science, Chung-Ang University, Seoul 156-756, Republic of Korea

The genus Tenacibaculum, proposed by Suzuki et al. (2001) to reclassify two former species of Flexibacter, belongs to the family Flavobacteriaceae. At the time of writing, the genus contains 14 species with validly published names, including the recently described species Tenacibaculum discolor and T. gallaicum (Piñeiro-Vidal et al., 2008a), T. adriaticum (Heindl et al., 2008), T. aiptasiae (Wang et al., 2008) and T. soleae (Piñeiro-Vidal et al., 2008b). Tenacibaculum strains are widespread in the marine environment and have been isolated from marine animals (Wakabayashi et al., 1986; Hansen et al., 1992; Suzuki et al., 2001; Piñeiro-Vidal et al., 2008a, b; Heindl et al., 2008; Wang et al., 2008), macroalgae (Suzuki et al., 2001), tidal flats (Yoon et al., 2005; Choi et al., 2006; Jung et al., 2006) and seawater (Frette et al., 2004; Sheu et al., 2007).

\footnotetext{
The GenBank accession number for the 16S rRNA gene sequence of strain $\mathrm{JO}-1^{\top}$ is EU428783.

A scanning electron micrograph of cells of strain $\mathrm{JO}-1^{\top}$ is available as a supplementary figure with the online version of this paper.
}

Tenacibaculum maritimum, T. gallaicum, T. discolor and T. ovolyticum are pathogenic for many farmed marine fish (Piñeiro-Vidal et al., 2008c). In particular, T. maritimum is the causative agent of the well-known bacterial disease tenacibaculosis, which causes severe necrotic and ulcerative lesions on the body surface of a variety of valuable marine fish worldwide (Avendaño-Herrera et al., 2006). T. soleae and T. aiptasiae were isolated from a diseased sole and sea anemone, respectively. In this study, a bacterium, designated strain JO- ${ }^{\mathrm{T}}$, was isolated from an apparently healthy Pacific oyster, Crassostrea gigas, and its taxonomic position was investigated using a polyphasic approach.

Strain JO- ${ }^{\mathrm{T}}$ was isolated from a homogenized oyster sample collected from Wan Island ( $34^{\circ} 20^{\prime} \mathrm{N} 126^{\circ} 44^{\prime} \mathrm{E}$ ), Korea. The sample was serially diluted with sterile artificial seawater (Lyman \& Fleming, 1940), spread on marine agar 2216 (MA; Difco) and incubated at $30{ }^{\circ} \mathrm{C}$ for 3 days. A colony was selected and subcultured on MA for further characterization. The isolate was preserved in marine broth 2216 (MB) supplemented with $20 \%(\mathrm{v} / \mathrm{v})$ glycerol at $-80{ }^{\circ} \mathrm{C}$. 
Table 1. Differential phenotypic characteristics of strain $\mathrm{JO}-1^{\top}$ and the type strains of other Tenacibaculum species

Strains: 1, Tenacibaculum crassostreae sp. nov. JO-1 ${ }^{\mathrm{T}} ; 2$, T. adriaticum $\mathrm{B} 390^{\mathrm{T}} ; 3$, T. discolor LL04 11.1.1 ${ }^{\mathrm{T}} ; 4$, T. gallaicum A37.1 ${ }^{\mathrm{T}} ; 5$, T. litopenaei B-I ${ }^{\mathrm{T}} ; 6$, T. amylolyticum MBIC4355 $5^{\mathrm{T}} ;$, T. aestuarii SMK-4 $4^{\mathrm{T}} ; 8$, T. litoreum CL-TF13 $3^{\mathrm{T}}$ 9 9, T. lutimaris TF-26 ${ }^{\mathrm{T}} ; 10$, T. maritimum NCIMB $2154^{\mathrm{T}} ; 11$, T. mesophilum MBIC1140 ${ }^{\mathrm{T}} ; 12$, T. ovolyticum IAM $14318^{\mathrm{T}} ; 13$, T. skagerrakense D30 $; 14$, T. soleae LL04 12.1. ${ }^{\mathrm{T}}$; 15, T. aiptasiae $4^{\mathrm{T}}$. Data from Suzuki et al. (2001), Frette et al. (2004), Yoon et al. (2005), Choi et al. (2006), Jung et al. (2006), Sheu et al. (2007), Heindl et al. (2008), Piñeiro-Vidal et al. (2008a, b) and Wang et al. (2008). +, Positive; -, negative; ND, no data available; NG, no growth; w, weakly positive.

\begin{tabular}{|c|c|c|c|c|c|c|c|c|c|c|c|c|c|c|c|}
\hline Characteristic & 1 & 2 & 3 & 4 & 5 & 6 & 7 & 8 & 9 & 10 & 11 & 12 & 13 & 14 & 15 \\
\hline Gliding motility & + & ND & + & + & + & $+{ }^{a_{*}}$ & + & + & $+{ }^{a}$ & $+{ }^{a}$ & $+{ }^{a}$ & $+{ }^{a}$ & $-{ }^{a}$ & + & + \\
\hline Pigmentation $\dagger$ & TY & TY & BY & BY & $\mathrm{Y}$ & $\mathrm{Y}$ & PY & PY & PY & PY & $\mathrm{Y}$ & PY & BY & $\mathrm{Y}$ & PY \\
\hline $\begin{array}{l}\text { Occurrence of spherical cells in } \\
\text { ageing broth } \ddagger\end{array}$ & $\mathrm{R}$ & ST & $\mathrm{R}$ & $\mathrm{R}$ & VR & $\mathrm{VR}^{a}$ & ND & VR & VR & $\mathrm{F}^{a}$ & $\mathrm{VR}^{a}$ & NO & F & $\mathrm{F}$ & VR \\
\hline \multicolumn{16}{|l|}{ Ranges for growth } \\
\hline $\mathrm{NaCl}(\%)$ & NG & $1-5$ & NG & NG & $2-10$ & $3(w)$ & $<7$ & $3-5$ & $<8^{a}$ & NG & $1-7$ & NG & NG & NG & $1-10$ \\
\hline Seawater $(\%) \S$ & $75-175$ & $12.5-175$ & $30-100$ & $30-100$ & $\mathrm{ND}$ & $50-100$ & $\mathrm{ND}$ & $25-250$ & $25-175^{a}$ & $30-100$ & $10-100$ & $70-100$ & $25-150$ & $55-100$ & ND \\
\hline $\mathrm{pH}$ & $6.0-7.0$ & $5.0-9.0$ & $6.0-8.0$ & $6.0-8.0$ & $5.0-10.0$ & $5.3-8.3$ & $5.5-8.5$ & $6.0-10.0$ & $7.0-8.0$ & $5.9-8.6$ & $5.3-9.0$ & $5.9-9.0$ & $6.0-9.0$ & $6.0-8.0$ & $7.0-9.0$ \\
\hline Temperature $\left({ }^{\circ} \mathrm{C}\right)$ & $15-37$ & $5-33.5$ & $14-38$ & $14-38$ & $10-39$ & $20-35$ & $9-41$ & $5-40$ & $10-39$ & $15-34$ & $15-40$ & $4-25$ & $10-40$ & $14-30$ & $8-40$ \\
\hline Temperature optimum $\left({ }^{\circ} \mathrm{C}\right)$ & 30 & $18-26$ & $25-30$ & $25-30$ & $28-37$ & $27-30$ & $30-37$ & $35-40$ & $30-37$ & 30 & $28-35$ & ND & $25-37$ & $22-25$ & $30-35$ \\
\hline Nitrate reduction & - & - & + & + & - & $\mathrm{w}$ & - & + & - & + & - & + & + & $\mathrm{ND}$ & - \\
\hline \multicolumn{16}{|l|}{ Hydrolysis of: } \\
\hline Chitin & - & - & $\mathrm{ND}$ & ND & + & - & ND & ND & ND & - & - & + & $-{ }^{b}$ & ND & - \\
\hline Starch & + & + & - & - & + & + & - & + & - & - & - & - & + & - & + \\
\hline Gelatin & + & + & + & + & + & + & + & + & + & - & + & + & ND & + & + \\
\hline Tween 80 & + & - & - & - & - & $+{ }^{a}$ & + & + & - & $++^{a}$ & $++^{a}$ & $+{ }^{a}$ & $-{ }^{a}$ & - & + \\
\hline \multicolumn{16}{|l|}{ API ZYM tests } \\
\hline Lipase (C14) & - & ND & + & + & + & $\mathrm{ND}$ & - & - & $-{ }^{a}$ & $\mathrm{w}^{a}$ & $\mathrm{ND}$ & ND & $\mathrm{ND}$ & + & + \\
\hline Trypsin & + & $\mathrm{ND}$ & + & + & - & $\mathrm{ND}$ & - & + & + & $\mathrm{w}^{a}$ & $\mathrm{ND}$ & $\mathrm{ND}$ & $\mathrm{ND}$ & - & + \\
\hline $\begin{array}{l}\text { Naphthol-AS-BI-phosphohy- } \\
\text { drolase }\end{array}$ & + & $\mathrm{ND}$ & + & + & + & $\mathrm{ND}$ & + & + & $+^{a}$ & $\mathrm{w}^{a}$ & $\mathrm{ND}$ & ND & $\mathrm{ND}$ & - & + \\
\hline \multicolumn{16}{|l|}{ Utilization of: } \\
\hline Citrate & - & - & $\mathrm{ND}$ & ND & - & $-{ }^{a}$ & ND & - & $\mathrm{ND}$ & $-{ }^{a}$ & $-{ }^{a}$ & $-{ }^{a}$ & $+{ }^{a}$ & ND & - \\
\hline L-Leucine & - & $\mathrm{w}$ & $\mathrm{ND}$ & ND & - & $-{ }^{a}$ & - & - & - & $-{ }^{a}$ & $-{ }^{a}$ & $-{ }^{a}$ & $\mathrm{w}$ & ND & - \\
\hline L-Proline & + & + & + & + & + & + & - & + & - & - & + & - & $+{ }^{a}$ & - & - \\
\hline L-Glutamate & + & + & + & + & + & + & - & - & - & $\mathrm{w}^{a}$ & + & - & $+^{a}$ & - & + \\
\hline DL-Aspartate & + & + & ND & ND & - & - & - & - & - & - & + & - & + & ND & + \\
\hline$\alpha$-D-Glucose & - & + & - & - & + & $\mathrm{ND}$ & - & - & $-{ }^{a}$ & $\mathrm{ND}$ & $\mathrm{ND}$ & $\mathrm{ND}$ & $+{ }^{a}$ & - & - \\
\hline Sucrose & - & $\mathrm{ND}$ & - & - & - & - & - & - & - & - & - & - & + & - & - \\
\hline DNA G $+\mathrm{C}$ content $(\mathrm{mol} \%) \|$ & 31.4 & 31.6 & 32.1 & 32.7 & 35.2 & 30.9 & 33.6 & 30 & $32.3-32.8$ & $31.3-32.5$ & $31.6-32.0$ & $30.3-32.0$ & 35.2 & 29.8 & 35.0 \\
\hline
\end{tabular}

${ }^{*}$ Data from: $a$, Choi et al. (2006); b, Sheu et al. (2007).

$\dagger \mathrm{BY}$, Bright yellow; PY, pale yellow; TY, translucent yellow; Y, yellow.

$\ddagger F$, Frequent; R, rare; VR, very rare; ST, in stationary phase; NO, not observed.

$\$$ Calculated on the basis of $100 \%$ seawater being equivalent to $40 \mathrm{~g}$ artificial sea salts $1^{-1}$ (Frette et al., 2004).

IIRanges of values represent data for four (T. lutimaris and T. mesophilum), three (T. ovolyticum) or two (T. maritimum) strains, including the respective type strains. 
The minimal standards for describing new taxa in the family Flavobacteriaceae (Bernardet et al., 2002) were used to describe strain $\mathrm{JO}-1^{\mathrm{T}}$. The optimal temperature and temperature range for growth was tested on MA at 4, $10,15,20,25,30,35,37,40,42,45$ and $50{ }^{\circ} \mathrm{C}$. Tolerance to sea salts was determined on ZoBell agar [containing $\left(1^{-1}\right.$ distilled water): $5 \mathrm{~g}$ Bacto peptone, $1 \mathrm{~g}$ yeast extract, $0.1 \mathrm{~g}$ ferric citrate, $15 \mathrm{~g}$ Bacto agar (ZoBell, 1941)] with $0-10 \%(\mathrm{w} / \mathrm{v})$ sea salts (Sigma) at $1.0 \%$ intervals. Growth with $\mathrm{NaCl}$ as the sole salt was tested on ZoBell agar supplemented with $3 \% \mathrm{NaCl}$. The $\mathrm{pH}$ range for growth was assessed on ZoBell agar containing $2 \%$ sea salts and adjusted to $\mathrm{pH} 3.0-11.0$ (at $1.0 \mathrm{pH}$ unit intervals) with $\mathrm{HCl}$ or $\mathrm{NaOH}$ before sterilization. Only minor changes in $\mathrm{pH}$ were noticed after sterilization. Cell morphology was examined by scanning electron microscopy (S-4800; Hitachi) using cells grown overnight at $30{ }^{\circ} \mathrm{C}$ in $\mathrm{MB}$. Gliding motility was tested by the hanging-drop method (Suzuki et al., 2001). Anaerobic growth on MA was tested using the AnaeroPack-Anaero (Mitsubishi Gas Chemical) for up to 10 days. Catalase and oxidase activities were determined using standard methods (Tindall et al., 2007). Hydrolysis of casein, chitin, starch and Tween 80 was examined using MA supplemented with $1 \%$ substrate as described by Hansen \& Sørheim (1991). Antibiotic resistance was determined with the disc diffusion method using commercial antibioticimpregnated discs (BBL; Becton Dickson). The results were interpreted according to the guidelines described by the CLSI (2003). The presence of flexirubin-type pigments was examined as described by Bernardet et al. (2002). Other biochemical characteristics of strain JO- ${ }^{\mathrm{T}}$ were determined using API 20E, API 20NE and API ZYM test kits (bioMérieux) and the utilization of different carbon sources was tested with the GN2 MicroPlate system (Biolog). All kits were used according to the manufacturers' instructions and the bacterial suspensions were prepared in artificial seawater or $2 \%$ sea salts. Detailed results of morphological, physiological and biochemical tests are given in the species description and in Table 1.

Bacterial genomic DNA was extracted using a commercial kit (Bioneer). The 16S rRNA gene sequence was amplified by using the universal bacterial primers $27 \mathrm{f}$ and $1525 \mathrm{r}$ (Lane, 1991) and the purified PCR product was sequenced. The almost-complete gene sequence from strain $\mathrm{JO}-\mathrm{1}^{\mathrm{T}}$ (1394 bp) was aligned with the CLUSTAL $\mathrm{W}$ program (Thompson et al., 1994) against sequences obtained from the GenBank database. Phylogenetic trees were inferred from the regions available for all sequences using the FitchMargoliash (Fitch \& Margoliash, 1967) and neighbourjoining (Saitou \& Nei, 1987) methods. Evolutionary distance matrices were generated according to Jukes \& Cantor (1969). The tree topologies obtained were evaluated by bootstrap analyses (Felsenstein, 1981) of the neighbourjoining method based on 1000 resamplings. The alignment and phylogenetic analysis were carried out using the jPHYDIT program (available at http://chunlab.snu.ac.kr/ jphydit/) and PAUP 4.0 (Swofford, 1998) as described by Chun et al. (2000).

Initial similarity analyses of $16 \mathrm{~S}$ rRNA gene sequences indicated that strain $\mathrm{JO}-1^{\mathrm{T}}$ was closely related to members of the genus Tenacibaculum as follows: T. litoreum CL$\mathrm{TF}^{\mathrm{T}}{ }^{\mathrm{T}}(97.8 \%), T$. discolor LL04 11.1.1 ${ }^{\mathrm{T}}$ (97.7\%), $T$. adriaticum $\mathrm{B} 390^{\mathrm{T}}(97.6 \%)$, T. lutimaris $\mathrm{TF}-26^{\mathrm{T}}(97.1 \%)$, T. aiptasiae $\mathrm{a}^{\mathrm{T}}(96.9 \%)$, T. soleae LL04 12.1.7 ${ }^{\mathrm{T}}(96.9 \%)$, T. aestuarii SMK-4 ${ }^{\mathrm{T}}$ (96.8\%), T. mesophilum MBIC $1140^{\mathrm{T}}$ (96.7\%), T. gallaicum A37.1 ${ }^{\mathrm{T}}$ (96.6\%), T. litopenaei B- $\mathrm{I}^{\mathrm{T}}$ (95.7\%), T. skagerrakense $\mathrm{D} 30^{\mathrm{T}}(95.6 \%)$, T. amylolyticum MBIC4355 ${ }^{\mathrm{T}}(95.2 \%)$, T. ovolyticum IAM $14318^{\mathrm{T}}(94.7 \%)$ and T. maritimum IFO $15946^{\mathrm{T}}(94.6 \%)$. Strain JO- ${ }^{\mathrm{T}}$ occupied a distinct position in the neighbour-joining tree (Fig. 1). The tree based on the Fitch-Margoliash method showed essentially the same topology (not shown).

The DNA G $+\mathrm{C}$ content was $31.4 \mathrm{~mol} \%$ as determined using the thermal denaturation method (Marmur \& Doty,

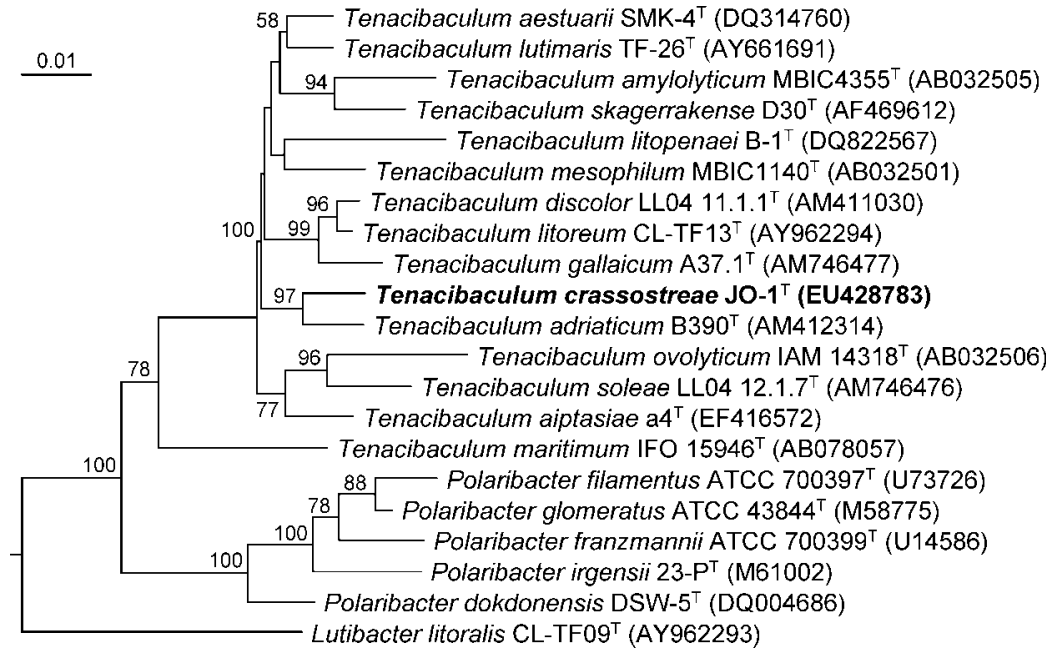

Fig. 1. Neighbour-joining phylogenetic tree based on nearly complete 16S rRNA gene sequences showing the relationships between strain $\mathrm{JO}-1^{\top}$, other members of the genus Tenacibaculum and related genera of the family Flavobacteriaceae. Percentages at nodes are levels of bootstrap support $(>50 \%)$ based on neighbour-joining analyses of 1000 resampled datasets. The sequence of Cellulophaga lytica ATCC $23178^{\top}$ (GenBank accession no. M62796; not shown) was used as an outgroup. Bar, 0.01 substitutions per nucleotide position. 
1962). For fatty acid analysis, cells grown on MA at $28{ }^{\circ} \mathrm{C}$ for $48 \mathrm{~h}$ were prepared and analysed by GLC according to the instructions of the Microbial Identification System (MIDI Inc., 1999). The predominant cellular fatty acids of strain $\mathrm{JO}-1^{\mathrm{T}}$ were iso- $\mathrm{C}_{15: 0}(23.7 \%)$, summed feature 3 (comprising $\mathrm{C}_{16: 1} \omega 7 c$ and/or iso- $\mathrm{C}_{15: 0} 2-\mathrm{OH} ; 14.5 \%$ ) and iso- $\mathrm{C}_{15: 1} \mathrm{G}(14.1 \%)$. The detailed fatty acid profile of strain JO- $1^{\mathrm{T}}$ is compared with those of members of the genus Tenacibaculum in Table 2.
DNA-DNA hybridization was performed by the membrane filter technique using the DIG High Prime DNA Labelling and Detection Starter kit II (Roche Molecular Biochemicals) according to the method described in detail by Lee et al. (2003), with the modification that the hybridization temperature was $45^{\circ} \mathrm{C}$. Strain JO- $1^{\mathrm{T}}$ showed relatively low DNA-DNA relatedness to $T$. adriaticum JCM $14633^{\mathrm{T}}(27.7 \%)$, T. litoreum KCCM $42115^{\mathrm{T}}(27.7 \%), T$. aestuarii $\mathrm{KCTC} 12569^{\mathrm{T}}(26.6 \%)$, T. lutimaris KCTC

Table 2. Cellular fatty acid compositions of strain $\mathrm{JO}-1^{\top}$ and the type strains of other Tenacibaculum species

Strains: 1, T. crassostreae sp. nov. JO- $1^{\mathrm{T}} ; 2$, T. adriaticum $\mathrm{B} 390^{\mathrm{T}} ; 3$, T. litopenaei B-I ${ }^{\mathrm{T}} ; 4$, T. aestuarii SMK- $4^{\mathrm{T}} ; 5$, T. litoreum KCCM 42115 ${ }^{\mathrm{T}} ; 6$, T. lutimaris TF-26 ${ }^{\mathrm{T}}$; 7, T. maritimum JCM 8137 ${ }^{\mathrm{T}}$, 8, T. mesophilum MBIC1140 ${ }^{\mathrm{T}}$; 9, T. skagerrakense DSM 14836 ${ }^{\mathrm{T}}$; 10, T. soleae LL04 12.1.7 $7^{\mathrm{T}}$; 11, T. aiptasiae $\mathrm{a}^{\mathrm{T}}$. Data from Yoon et al. (2005), Choi et al. (2006), Jung et al. (2006), Sheu et al. (2007), Heindl et al. (2008), Piñeiro-Vidal et al. (2008c) and Wang et al. (2008). No data available for T. amylolyticum, T. discolor, T. gallaicum or T. ovolyticum. Values are expressed as percentages of total fatty acids, with those amounting to less than $1 \%$ in all strains not listed. Some strains were grown under different culture conditions. - , Not detected; tr, trace $(<1 \%)$; ECL, equivalent chain-length.

\begin{tabular}{|c|c|c|c|c|c|c|c|c|c|c|c|}
\hline Fatty acid & 1 & 2 & 3 & 4 & 5 & 6 & 7 & 8 & 9 & 10 & 11 \\
\hline \multicolumn{12}{|l|}{ Straight-chain } \\
\hline $\mathrm{C}_{15: 0}$ & 2.6 & 2.7 & - & 6.1 & 2.7 & 8.9 & 2.9 & 3.6 & 4.9 & 4.8 & - \\
\hline $\mathrm{C}_{18: 0}$ & 3.8 & - & - & - & $\operatorname{tr}$ & - & 1.4 & - & - & - & - \\
\hline \multicolumn{12}{|l|}{ Branched } \\
\hline iso- $\mathrm{C}_{13: 0}$ & $\operatorname{tr}$ & 1.6 & $\operatorname{tr}$ & 1.3 & 1.4 & $\operatorname{tr}$ & 1.8 & $\operatorname{tr}$ & $\operatorname{tr}$ & $\operatorname{tr}$ & - \\
\hline iso- $\mathrm{C}_{15: 0}$ & 23.8 & 25.3 & 22.0 & 18.9 & 18.8 & 17.2 & 16.8 & 13.2 & $\operatorname{tr}$ & 23.1 & 12.9 \\
\hline anteiso- $\mathrm{C}_{15: 0}$ & 1.7 & $\operatorname{tr}$ & $\operatorname{tr}$ & 1.3 & 1.8 & $\operatorname{tr}$ & $\operatorname{tr}$ & 1.1 & - & $\operatorname{tr}$ & - \\
\hline iso- $\mathrm{C}_{15: 1} \mathrm{G}$ & 14.1 & - & - & - & - & - & - & - & - & - & - \\
\hline iso- $\mathrm{C}_{15: 1}$ & - & 13.1 & 8.7 & 8.7 & 8.2 & 5.3 & 7.6 & 7.1 & 8.2 & 5.7 & 9.5 \\
\hline iso- $\mathrm{C}_{16: 0}$ & 2.2 & $\operatorname{tr}$ & 1.8 & 2.0 & 2.3 & 3.8 & $\operatorname{tr}$ & 1.7 & 1.3 & 1.7 & 2.8 \\
\hline iso- $\mathrm{C}_{16: 1}$ & - & $\operatorname{tr}$ & 1.6 & 2.3 & 1.3 & 1.7 & - & $\operatorname{tr}$ & 1.7 & 2.4 & 2.3 \\
\hline $\mathrm{C}_{18: 1} \omega 5 c$ & $\operatorname{tr}$ & 1.2 & - & - & - & - & - & - & - & - & - \\
\hline $\mathrm{C}_{18: 3} \omega 6 c$ & - & - & - & - & 1.5 & - & - & - & - & - & - \\
\hline \multicolumn{12}{|l|}{ Hydroxy } \\
\hline $\mathrm{C}_{15: 0} 2-\mathrm{OH}$ & $\operatorname{tr}$ & $\operatorname{tr}$ & $\operatorname{tr}$ & $\operatorname{tr}$ & $\operatorname{tr}$ & 1.2 & 1.1 & 1.1 & 2.5 & $\operatorname{tr}$ & 1.9 \\
\hline $\mathrm{C}_{15: 0} 3-\mathrm{OH}$ & $\operatorname{tr}$ & 3.2 & 2.7 & 4.2 & - & 3.4 & 3.8 & 2.9 & 8.6 & 3.2 & 4.4 \\
\hline $\mathrm{C}_{16: 0} 3-\mathrm{OH}$ & 1.6 & $\operatorname{tr}$ & 5.4 & 1.0 & 1.6 & 1.3 & 1.5 & 3.2 & 2.1 & 2.2 & 3.8 \\
\hline $\mathrm{C}_{17: 0} 3-\mathrm{OH}$ & $\operatorname{tr}$ & - & 1.0 & $\operatorname{tr}$ & $\operatorname{tr}$ & $\operatorname{tr}$ & $\operatorname{tr}$ & $\operatorname{tr}$ & 2.5 & - & 1.8 \\
\hline iso- $\mathrm{C}_{15: 0} 3-\mathrm{OH}$ & 5.4 & 13.7 & 4.6 & 6.1 & 6.6 & 4.6 & 19.8 & 8.0 & 7.8 & 10.6 & 6.9 \\
\hline iso- $\mathrm{C}_{16: 0} 3-\mathrm{OH}$ & 6.6 & 2.8 & 3.4 & 12.3 & 6.8 & 12.8 & 5.0 & 9.0 & 12.2 & 8.4 & 10.2 \\
\hline iso- $\mathrm{C}_{17: 0} 3-\mathrm{OH}$ & 6.7 & 10.8 & 12.7 & 9.6 & 13.6 & 8.4 & 13.7 & 14.9 & 11.7 & 2.9 & 9.9 \\
\hline \multicolumn{12}{|l|}{ Unknown } \\
\hline
\end{tabular}

* Summed features are groups of two or three fatty acids that cannot be separated by GLC with the MIDI system. Summed feature 1 contained one or more of iso- $\mathrm{C}_{15: 1} \mathrm{H}$, iso- $\mathrm{C}_{15: 1} \mathrm{I}$ and $\mathrm{C}_{13: 0} 3-\mathrm{OH}$. Summed feature 3 contained $\mathrm{C}_{16: 1} \omega 7 c$ and/or iso- $\mathrm{C}_{15: 0}$ 2-OH. Summed feature 4 contained iso- $\mathrm{C}_{17: 1} \mathrm{I}$ and/or anteiso- $\mathrm{C}_{17: 1} \mathrm{~B}$. 


\section{$12302^{\mathrm{T}}(21.0 \%)$ and T. mesophilum DSM $13764^{\mathrm{T}}$ $(19.9 \%)$.}

On the basis of the phenotypic and molecular genetic data, it is suggested that strain JO- $1^{\mathrm{T}}$ represents a novel species of the genus Tenacibaculum, for which the name Tenacibaculum crassostreae sp. nov. is proposed.

\section{Description of Tenacibaculum crassostreae sp. nov.}

Tenacibaculum crassostreae (cra.sso.stre'ae. N.L. gen. n. crassostreae pertaining to Crassostrea, the scientific genus name of the Pacific oyster, C. gigas, from which the type strain was isolated).

Cells are Gram-negative, aerobic, straight rods, motile by gliding, approximately $0.3 \mu \mathrm{m}$ in diameter and $1.5-5.0 \mu \mathrm{m}$ long. On MA, colonies are translucent yellow, circular, low-convex, with regular edges. After 5 days on MA at $30{ }^{\circ} \mathrm{C}$, colonies are approximately $5 \mathrm{~mm}$ in diameter. No growth occurs with $\mathrm{NaCl}$ only. Growth occurs with 3-7\% $(w / v)$ sea salts. Growth occurs at $15-37{ }^{\circ} \mathrm{C}$ (optimum $30{ }^{\circ} \mathrm{C}$ ) but not at $40{ }^{\circ} \mathrm{C}$. The $\mathrm{pH}$ range for growth is $\mathrm{pH}$ 6.0-7.0. Flexirubin-type pigments are absent. Positive for catalase and oxidase. Casein, starch and Tween 80 are hydrolysed, but chitin is not hydrolysed. According to API ZYM tests, activities for esterase (C4), esterase lipase (C8), leucine arylamidase, valine arylamidase, trypsin, acid phosphatase and naphthol-AS-BI-phosphohydrolase are present, whereas activities for alkaline phosphatase, lipase (C14), cystine arylamidase, $\alpha$-chymotrypsin, $\alpha$-galactosidase, $\beta$-galactosidase, $\beta$-glucuronidase, $\alpha$-glucosidase, $\beta$ glucosidase, $N$-acetyl $\beta$-glucosaminidase, $\alpha$-mannosidase and $\alpha$-fucosidase are absent. API 20E and API 20NE kits yield a positive reaction for gelatinase and negative reactions for nitrate reduction, indole and $\mathrm{H}_{2} \mathrm{~S}$ production, glucose fermentation, aesculin hydrolysis and urease and arginine dihydrolase. The following substrates are utilized with the Biolog GN2 MicroPlate system: dextrin, L-fucose, myo-inositol, mannitol, turanose, monomethyl succinate, D-glucosaminic acid, $\alpha$-ketobutyric acid, DL-lactic acid, succinic acid, L-alanyl glycine, L-asparagine, L-aspartic acid, L-glutamic acid, glycyl L-aspartic acid, glycyl Lglutamic acid, hydroxy L-proline, L-ornithine, L-proline and thymidine. The remaining substrates in the GN2 MicroPlate are not utilized. The type strain is sensitive to ( $\mu \mathrm{g}$ per disc unless otherwise stated) ampicillin (10), chloramphenicol (30), erythromycin (15), penicillin (10 IU), nalidixic acid (30), tetracycline (30) and vancomycin (30), but resistant to amikacin (30), gentamicin (10), kanamycin (30), polymyxin B (300 IU) and streptomycin (10). The major fatty acids $(>14 \%)$ are iso$\mathrm{C}_{15: 0}$, iso- $\mathrm{C}_{15: 1} \mathrm{G}$ and summed feature 3 (comprising iso$\mathrm{C}_{15: 0} 2-\mathrm{OH}$ and/or $\mathrm{C}_{16: 1} \omega 7 c$ ). The DNA G $+\mathrm{C}$ content of the type strain is $31.4 \mathrm{~mol} \%$.

The type strain is JO- $1^{\mathrm{T}}\left(=\mathrm{KCTC} 22329^{\mathrm{T}}=\mathrm{JCM} 15428^{\mathrm{T}}\right)$, isolated from a Pacific oyster, Crassostrea gigas, collected from Wan Island, Jeonnam province, Korea.

\section{References}

Avendaño-Herrera, R., Toranzo, A. E. \& Magariños, B. (2006). Tenacibaculosis infection in marine fish caused by Tenacibaculum maritimum: a review. Dis Aquat Organ 71, 255-266.

Bernardet, J.-F., Nakagawa, Y. \& Holmes, B. (2002). Proposed minimal standards for describing new taxa of the family Flavobacteriaceae and emended description of the family. Int J Syst Evol Microbiol 52, 1049-1070.

Choi, D. H., Kim, Y.-G., Hwang, C. Y., Yi, H., Chun, J. \& Cho, B. C. (2006). Tenacibaculum litoreum sp. nov., isolated from tidal flat sediment. Int J Syst Evol Microbiol 56, 635-640.

Chun, J., Bae, K. S., Moon, E. Y., Jung, S. O., Lee, H. K. \& Kim, S. J. (2000). Norcardiopsis kunsanensis sp. nov., a moderately halophilic actinomycetes isolated from a saltern. Int J Syst Evol Microbiol 50, 1909-1913.

CLSI (2003). Performance standards for antimicrobial disk susceptibility tests, Approved Standard, 8th edn. Wayne, PA: Clinical Laboratory Standards Institute.

Felsenstein, J. (1981). Evolutionary trees from DNA sequences: a maximum likelihood approach. J Mol Evol 17, 368-376.

Fitch, W. M. \& Margoliash, E. (1967). Construction of phylogenetic trees. Science 155, 279-284.

Frette, L., Jørgensen, N. O. G., Irming, H. \& Kroer, N. (2004). Tenacibaculum skagerrakense sp. nov., a marine bacterium isolated from the pelagic zone in Skagerrak, Denmark. Int J Syst Evol Microbiol 54, 519-524.

Hansen, G. H. \& Sørheim, R. (1991). Improved method for phenotypical characterization of marine bacteria. I Microbiol Methods 13, 231-241.

Hansen, G. H., Bergh, Ø., Michaelsen, J. \& Knappskog, D. (1992). Flexibacter ovolyticus sp. nov., a pathogen of eggs and larvae of Atlantic halibut, Hippoglossus hippoglossus L. Int J Syst Bacteriol 42, 451-458.

Heindl, H., Wiese, J. \& Imhoff, J. F. (2008). Tenacibaculum adriaticum sp. nov., from a bryozoan in the Adriatic Sea. Int J Syst Evol Microbiol 58, 542-547.

Jukes, T. H. \& Cantor, C. R. (1969). Evolution of protein molecules. In Mammalian Protein Metabolism, vol. 3, pp. 21-132. Edited by H. N. Munro. New York: Academic Press.

Jung, S.-Y., Oh, T.-K. \& Yoon, J.-H. (2006). Tenacibaculum aestuarii sp. nov., isolated from a tidal flat sediment in Korea. Int J Syst Evol Microbiol 56, 1577-1581.

Lane, D. J. (1991). 16S/23S rRNA sequencing. In Nucleic Acid Techniques in Bacterial Systematics, pp. 115-175. Edited by E. Stackebrandt \& M. Goodfellow. Chichester: Wiley.

Lee, J.-S., Lee, K. C., Pyun, Y.-R. \& Bae, K. S. (2003). Arthrobacter koreensis sp. nov., a novel alkalitolerant bacterium from soil. Int J Syst Evol Microbiol 53, 1277-1280.

Lyman, J. \& Fleming, R. H. (1940). Composition of sea water. J Mar Res 3, 134-146.

Marmur, J. \& Doty, P. (1962). Determination of the base composition of deoxyribonucleic acid from its thermal denaturation temperature. $J$ Mol Biol 5, 109-118.

MIDI Inc. (1999). Sherlock Microbial Identification System Operating Manual, version 3.0. Newark, DE: MIDI.

Piñeiro-Vidal, M., Riaza, A. \& Santos, Y. (2008a). Tenacibaculum discolor sp. nov. and Tenacibaculum gallaicum sp. nov., isolated from sole (Solea senegalensis) and turbot (Psetta maxima) culture systems. Int J Syst Evol Microbiol 58, 21-25. 
Piñeiro-Vidal, M., Carballas, C. G., Gómez-Barreiro, O., Riaza, A. \& Santos, Y. (2008b). Tenacibaculum soleae sp. nov., isolated from diseased sole (Solea senegalensis Kaup). Int J Syst Evol Microbiol 58, 881-885.

Piñeiro-Vidal, M., Pazos, F. \& Santos, Y. (2008c). Fatty acid analysis as a chemotaxonomic tool for taxonomic and epidemiological characterization of four fish pathogenic Tenacibaculum species. Lett Appl Microbiol 46, 548-554.

Saitou, N. \& Nei, M. (1987). The neighbor-joining method: a new method for reconstructing phylogenetic trees. Mol Biol Evol 4, 406-425.

Sheu, S.-Y., Lin, K.-Y., Chou, J.-H., Chang, P.-S., Arun, A. B., Young, C.-C. \& Chen, W.-M. (2007). Tenacibaculum litopenaei sp. nov., isolated from a shrimp mariculture pond. Int J Syst Evol Microbiol 57, 1148-1153.

Suzuki, M., Nakagawa, Y., Harayama, S. \& Yamamoto, S. (2001). Phylogenetic analysis and taxonomic study of marine Cytophaga-like bacteria: proposal for Tenacibaculum gen. nov., with Tenacibaculum maritimum comb. nov. and Tenacibaculum ovolyticum comb. nov., and description of Tenacibaculum mesophilum sp. nov. and Tenacibaculum amylolyticum sp. nov. Int J Syst Evol Microbiol 51, 1639-1652.

Swofford, D. L. (1998). Phylogenetic analysis using parsimony (PAUP), version 4. Sunderland, MA: Sinauer Associates.
Thompson, J. D., Higgins, D. G. \& Gibson, T. J. (1994). ClustAL W: improving the sensitivity of progressive multiple sequence alignment through sequence weighting, position-specific gap penalties and weight matrix choice. Nucleic Acids Res 22, 4673-4680.

Tindall, B. J., Sikorski, J., Smibert, R. A. \& Krieg, N. R. (2007). Phenotypic characterization and principles of comparative systematics. In Methods for General and Molecular Microbiology, pp. 330-393. Edited by C. A. Reddy, T. J. Beveridge, J. A. Breznak, G. A. Marzluf, T. M. Schmidt, \& L. R. Snyder. Washington, DC: American Society for Microbiology.

Wakabayashi, H., Hikida, M. \& Masumura, K. (1986). Flexibacter maritimus sp. nov., a pathogen of marine fishes. Int J Syst Bacteriol 36, 396-398.

Wang, J. T., Chou, Y. J., Chen, C. A. \& Chen, W. M. (2008). Tenacibaculum aiptasiae sp. nov., isolated from a sea anemone Aiptasia pulchella. Int J Syst Evol Microbiol 58, 761-766.

Yoon, J.-H., Kang, S.-J. \& Oh, T.-K. (2005). Tenacibaculum lutimaris sp. nov., isolated from a tidal flat in the Yellow Sea, Korea. Int J Syst Evol Microbiol 55, 793-798.

ZoBell, C. E. (1941). Studies on marine bacteria. I. The cultural requirements of heterotrophic aerobes. J Mar Res 4, 42-75. 